\title{
Prohepcidin, B-Type Natriuretic Peptide, and Iron Status in a Cohort of Elderly Women from the Rhine-Ruhr Area
}

\author{
Jana Henry ${ }^{a}$ Swaantje Casjens ${ }^{a}$ Tamara Schikowski ${ }^{d}$ Axel Stachon ${ }^{b}$ \\ Alfried Germing ${ }^{c} \quad$ Ulrich Ranft ${ }^{d}$ Martin Lehnert ${ }^{a}$ Volker Harth ${ }^{a}$ \\ Ursula Krämer $^{d}$ Thomas Brüning ${ }^{\text {a }}$ Beate Pesch ${ }^{a}$ \\ a Institute for Prevention and Occupational Medicine of the German Social Accident Insurance (IPA), \\ ${ }^{b}$ Institute of Clinical Chemistry, Transfusion, and Laboratory Medicine, and ${ }^{\mathrm{C} M e d i c a l}$ Clinic II, Cardiology and \\ Angiology, BG-University Hospital Bergmannsheil, Ruhr University Bochum, Bochum, and dEnvironmental Health \\ Research Institute (IUF), Düsseldorf, Germany
}

The elderly constitute a fast growing segment of populations worldwide. Both anemia and iron overload have emerged as risk factors that are associated with a variety of adverse outcomes in older adults [1-5]. Standard laboratory parameters like serum ferritin (SF), transferrin, transferrin saturation (Tsat), serum iron (SI), Hb, MCV, and HCT are commonly used for the assessment of iron status, but rapid progress has been made in understanding the regulation of iron metabolism by the hepatic peptide hormone hepcidin [6]. Hepcidin is synthesized in response to elevated plasma iron stores, thus ensuring homeostasis. Hepcidin synthesis is also increased by infection and inflammation. Increased hepcidin concentrations are of major importance in anemia of inflammation and iron-resistant iron deficiency anemia (IDA). On the other hand hepcidin is decreased in diseases that are attended by iron overload like most hereditary hemochromatoses or iron-loading anemias. A commercial assay for the measurement of serum hepcidin was not available at the time of the SALIA (Study on the influence of
Air pollution on Lung function, Inflammation and Aging) cohort investigation. Therefore, prohepcidin, the 84-amino acid precursor of hepcidin, was determined by a commercial assay to be a potential surrogate marker for hepcidin which can be used in routine laboratory examination. Some studies have investigated the association between prohepcidin and parameters of iron status, with conflicting results [7-17]. According to our knowledge, this parameter has not yet been determined in a population of elderly women.

Among different diseases associated with iron deficiency (ID) and anemia, anemia is common in patients with heart failure [18-20]. B-type natriuretic peptide (BNP) is a reliable marker of left ventricular dysfunction. Elevated BNP concentrations are associated with a poor outcome in patients with heart failure and coronary artery disease. Studies have shown that BNP concentrations in cardiac patients [21-23] and in the general population are inversely and independently related to $\mathrm{Hb}$ concentrations [24]. This suggests that elevated BNP concentra-

\section{KARGER}

Fax +4161306 1234 E-Mail karger@karger.ch www.karger.com
(C) 2010 S. Karger AG, Basel

$0001-5792 / 10 / 1243-0129 \$ 26.00 / 0$

Accessible online at:

www.karger.com/aha
Jana Henry, MD, Institut für Prävention und Arbeitsmedizin

der Deutschen Gesetzlichen Unfallversicherung

Institut der Ruhr-Universität Bochum (IPA)

Bürkle-de-la-Camp-Platz 1, DE-44789 Bochum (Germany)

Tel. +49 234302 4544, Fax +49 234302 4505, E-Mail henry@ ipa-dguv.de 
tions in anemic patients with chronic heart diseases are partially caused by anemia. If prohepcidin is a reliable biomarker for iron status, especially for anemia, an association of BNP with prohepcidin concentrations should be expected.

The SALIA cohort was part of a comprehensive environmental health survey on the effect of air pollution on women's health in the Rhine-Ruhr area [25-29]. Here we report on parameters of iron status in 319 women aged 69-79 years measured at follow-up in 2007/2008, including prohepcidin, and their association with BNP. All participants gave their written informed consent. The study was approved by the ethics commission of Ruhr University Bochum and was conducted in accordance with the definitions of the declaration of Helsinki.

WBC, RBC, MCV, Hb, HCT, SF, SI, transferrin, BNP, $\mathrm{C}$-reactive protein, alanine aminotransferase, aspartate aminotransferase, cholesterol, low-density lipoprotein cholesterol, high-density lipoprotein cholesterol, and triglycerides were analyzed with standard laboratory methods. Serum prohepcidin concentrations were analyzed in 1 batch using an ELISA kit (EIA-4644; DRG Instruments, Ltd., Marburg, Germany). The normal range of prohepcidin was given by the manufacturer (58.9-158.1 $\mathrm{ng} / \mathrm{ml})$.

Anemia was defined as $\mathrm{Hb}<12 \mathrm{~g} / \mathrm{dl}$ and $\mathrm{HCT}<36 \%$ for women according to the WHO. ID was defined as an abnormal value from 2 or 3 laboratory tests of iron status (SF, Tsat, and MCV) [30], and IDA was defined as ID plus $\mathrm{Hb}<12 \mathrm{~g} / \mathrm{dl}$. The definition of high iron stores is inconsistent throughout the literature, but it is well accepted that SF concentrations $>300 \mu \mathrm{g} / \mathrm{l}$ for men and $>200 \mu \mathrm{g} / \mathrm{l}$ for women are suitable cutoff criteria for high iron stores $[30,31]$. We used both thresholds for our calculations because several studies suggest $200 \mu \mathrm{g} / \mathrm{l}$ as the cutoff for SF in elderly women [32-34].

Figure 1 shows the distribution of prohepcidin in this cohort of elderly women [median $68.2 \mathrm{ng} / \mathrm{ml}$, interquartile range (IQR) 57.0-80.0]. The concentrations are, on average, lower than the measurements in 40 younger women provided by the manufacturer (median $85.6 \mathrm{ng}$ / $\mathrm{ml}$ IQR 72.9-91.5, $\mathrm{p}<0.0001$ ). This is in line with a few findings from smaller studies which suggest that prohepcidin concentrations are age- and gender-dependent $[12$, 13, 35-37].

The median concentrations of the standard measurements of iron status and other conditions fell within the reference range, except for cholesterol (data not shown). The prevalence rates of impaired iron status were low in this group of nonhospitalized women (table 1). On the basis of low $\mathrm{Hb}$ values ( $<12 \mathrm{~g} / \mathrm{dl}$ according to the WHO), $10(3.1 \%)$ women were classified as anemic with no further specification and 5 women (1.6\%) were classified as having ID. IDA was observed in 2 women. Although lim-
Fig. 1. Distribution of prohepcidin concentrations in 319 elderly women from the SALIA cohort and in a group of 40 women (data provided by DRG Instruments).

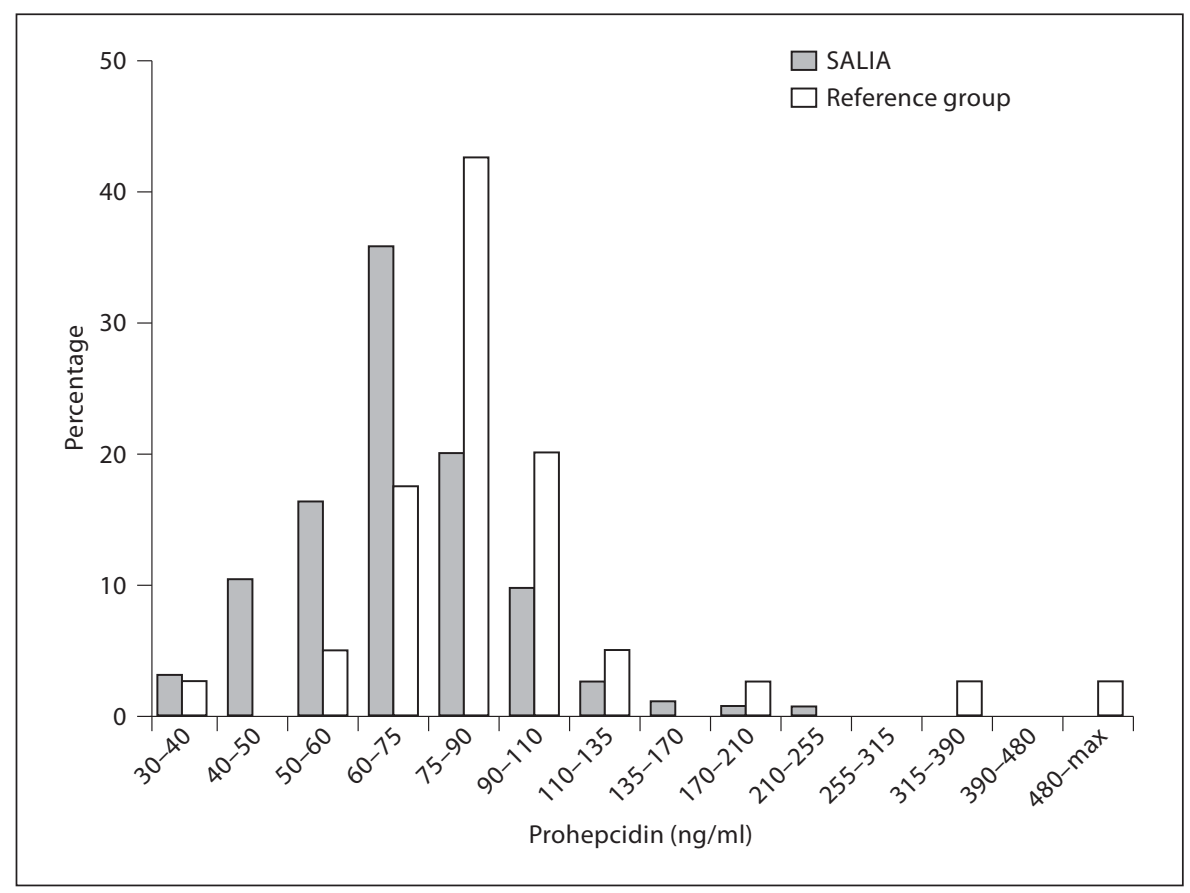


ited by a small number of cases, we found some evidence that ID and IDA were more common in the subgroup of women of a higher age ( $>73$ years). The low prevalence of ID and IDA in this study is in line with other investigations in healthy white women $[30,38]$.

Table 1. Iron status in elderly women from the SALIA cohort

\begin{tabular}{lccrc}
\hline & Cutoff & $\begin{array}{l}\text { All } \\
\text { women } \\
(\mathrm{n}=319)\end{array}$ & $\begin{array}{l}\text { Women } \\
\text { aged } \\
<73 \text { years } \\
(\mathrm{n}=179)\end{array}$ & $\begin{array}{l}\text { Women } \\
\text { aged } \\
(\mathrm{n}=13 \text { years }\end{array}$ \\
& & & & \\
\hline Laboratory variable & & & & \\
SF, $\mu$ g/l & $<15$ & $8(2.5)$ & $5(2.8)$ & $3(2.1)$ \\
SI, $\mu$ g/dl & $<60$ & $30(9.4)$ & $13(7.3)$ & $17(12.1)$ \\
Transferrin, mg/dl & $<200$ & $15(4.7)$ & $7(3.9)$ & $8(5.7)$ \\
Tsat, \% & $<16$ & $30(9.4)$ & $15(8.4)$ & $15(10.7)$ \\
Hb, g/dl & $<12$ & $10(3.1)$ & $2(1.1)$ & $8(5.7)$ \\
HCT, \% & $<36$ & $23(7.2)$ & $10(5.6)$ & $13(9.3)$ \\
MCV, fl & $<80$ & $2(0.6)$ & $1(0.6)$ & $1(0.7)$ \\
\hline Iron status & & & & \\
ID & & $5(1.6)$ & $2(1.1)$ & $3(2.1)$ \\
IDA & & $2(0.6)$ & $0(0.0)$ & $2(1.4)$ \\
High iron stores & & & & \\
$\quad$ SF, $\mu$ g/l & $>200$ & $37(11.6)$ & $23(12.8)$ & $14(10.0)$ \\
$\quad$ SF, $\mu$ g/l & $>300$ & $11(3.4)$ & $9(5.0)$ & $2(1.4)$ \\
\hline
\end{tabular}

Figures in parentheses are percentages.
We observed high iron stores more frequently in women below 73 years of age, independently of the 2 thresholds. Using the more commonly applied gender-specific cutoff for SF (>200 $\mu \mathrm{g} / \mathrm{l}), 11.6 \%$ of the SALIA women showed elevated iron stores which corresponds with the observations of $12.2 \%$ in the Framingham Heart Study cohort [30] and of $16.6 \%$ in healthy elderly Parisian women [39]. Using the higher cutoff $(>300 \mu \mathrm{g} / \mathrm{l})$ the prevalence was $3.4 \%$ in the SALIA cohort, $6 \%$ in the Framingham cohort, and 3.7\% in elderly Danish women [38].

Table 2 describes selected associations between iron status measures and other laboratory variables using Spearman's correlation coefficients $\left(r_{s}\right)$. No associations were found between prohepcidin and parameters of iron status and BNP, while BNP correlated inversely with standard parameters of iron status (Hb, HCT, SF, and SI). There was no correlation of BNP with risk factors for coronary artery disease like elevated triglycerides, cholesterol, and low-density lipoprotein cholesterol or lowered high-density lipoprotein cholesterol concentrations.

Data on the role of prohepcidin with regard to iron status are inconsistent. Some studies found an association between prohepcidin and parameters of iron status [7-11], while other studies did not [12-17]. The majority of these studies were limited by small numbers. According to our knowledge, SALIA is one of the largest study populations with prohepcidin analysis. We observed no association between prohepcidin and any marker of iron

Table 2. Spearman's correlation coefficients with $95 \%$ confidence limits between iron status measures and other laboratory variables in elderly women from the SALIA cohort

\begin{tabular}{|c|c|c|c|c|c|c|c|c|}
\hline Marker & Prohepcidin & SF & SI & Transferrin & Tsat & $\mathrm{Hb}$ & HCT & $\mathrm{MCV}$ \\
\hline Prohepcidin & 1.00 & & & & & & & \\
\hline SF & $\begin{array}{l}0.06 \\
(-0.05,0.17)\end{array}$ & 1.00 & & & & & & \\
\hline SI & $\begin{array}{l}-0.02 \\
(-0.13,0.09)\end{array}$ & $\begin{array}{l}0.24^{*} \\
(0.13,0.34)\end{array}$ & 1.00 & & & & & \\
\hline Transferrin & $\begin{array}{l}0.07 \\
(-0.04,0.18)\end{array}$ & $\begin{array}{l}-0.33^{*} \\
(-0.43,-0.23)\end{array}$ & $\begin{array}{l}0.08 \\
(-0.03,0.19)\end{array}$ & 1.00 & & & & \\
\hline Tsat & $\begin{array}{l}-0.07 \\
(-0.17,0.05)\end{array}$ & $\begin{array}{l}0.36^{*} \\
(0.26,0.45)\end{array}$ & $\begin{array}{l}0.85^{*} \\
(0.81,0.88)\end{array}$ & $\begin{array}{l}-0.40^{*} \\
(-0.49,-0.30)\end{array}$ & 1.00 & & & \\
\hline $\mathrm{Hb}$ & $\begin{array}{c}0.10 \\
(-0.01,0.21)\end{array}$ & $\begin{array}{l}0.13 \\
(0.02,0.24)\end{array}$ & $\begin{array}{l}0.40^{*} \\
(0.30,0.49)\end{array}$ & $\begin{array}{l}0.18^{*} \\
(0.08,0.29)\end{array}$ & $\begin{array}{l}0.25^{*} \\
(0.15,0.35)\end{array}$ & 1.00 & & \\
\hline HCT & $\begin{array}{l}0.09 \\
(-0.02,0.20)\end{array}$ & $\begin{array}{l}0.09 \\
(-0.02,0.20)\end{array}$ & $\begin{array}{l}0.35^{*} \\
(0.25,0.44)\end{array}$ & $\begin{array}{l}0.20^{*} \\
(0.09,0.30)\end{array}$ & $\begin{array}{l}0.20^{*} \\
(0.09,0.30)\end{array}$ & $\begin{array}{l}0.97^{*} \\
(0.96,0.98)\end{array}$ & 1.00 & \\
\hline $\mathrm{MCV}$ & $\begin{array}{l}-0.08 \\
(-0.19,0.03)\end{array}$ & $\begin{array}{l}0.31^{*} \\
(0.21,0.40)\end{array}$ & $\begin{array}{l}0.36^{*} \\
(0.26,0.45)\end{array}$ & $\begin{array}{l}-0.05 \\
(-0.16,0.06)\end{array}$ & $\begin{array}{l}0.35^{*} \\
(0.24,0.44)\end{array}$ & $\begin{array}{l}0.07 \\
(-0.04,0.18)\end{array}$ & $\begin{array}{l}0.03 \\
(-0.08,0.14)\end{array}$ & 1.00 \\
\hline $\mathrm{BNP}$ & $\begin{array}{l}-0.05 \\
(-0.16,0.06)\end{array}$ & $\begin{array}{l}-0.13 \\
(-0.24,-0.02)\end{array}$ & $\begin{array}{l}-0.11 \\
(-0.22,-0.0005)\end{array}$ & $\begin{array}{l}0.01 \\
(-0.10,0.12)\end{array}$ & $\begin{array}{l}-0.10 \\
(-0.21,0.01)\end{array}$ & $\begin{array}{l}-0.19^{*} \\
(-0.30,-0.08)\end{array}$ & $\begin{array}{l}-0.17 \\
(-0.27,-0.06)\end{array}$ & $\begin{array}{l}-0.08 \\
(-0.19,0.03)\end{array}$ \\
\hline
\end{tabular}

${ }^{*} \mathrm{p}<0.001$. 
status in nonhospitalized elderly women. The assumed association of prohepcidin as a reliable marker for iron status with BNP could not be confirmed in our study. This supports the conclusion that prohepcidin is likely not a suitable surrogate marker of the active form of the peptide hepcidin in healthy populations. Recent studies report that hepcidin concentrations in serum are much lower than prohepcidin concentrations are [40, 41]; thus, fluctuations in hepcidin levels might be associated with minor changes in prohepcidin concentrations. It is important to note that the ELISA assay might not be sufficiently specific for prohepcidin. It has been suggested that the antibody also recognizes the proregion of hepcidin [42]. Currently, a commercial immunoassay for human serum hepcidin is being developed [43] and will be investigated using stored SALIA samples.
In conclusion, a low prevalence of ID and anemia was observed in the SALIA cohort of healthy elderly women. Prohepcidin was not associated with the standard parameters of iron metabolism and BNP. We confirmed an expected negative correlation between iron status measures and BNP.

\section{Acknowledgement}

The work of the Environmental Health Research Institute (IUF) at the Heinrich Heine University of Düsseldorf was supported by a grant from the German Social Accident Insurance (DGUV).

\section{References}

1 Zakai NA, Katz R, Hirsch C, Shlipak MG, Chaves PH, Newman AB, Cushman M: A prospective study of anemia status, hemoglobin concentration, and mortality in an elderly cohort: the Cardiovascular Health Study. Arch Intern Med 2005;165:22142220 .

2 Culleton BF, Manns BJ, Zhang J, Tonelli M, Klarenbach S, Hemmelgarn BR: Impact of anemia on hospitalization and mortality in older adults. Blood 2006;107:3841-3846.

$\checkmark 3$ Levenson CW, Tassabehji NM: Iron and ageing: an introduction to iron regulatory mechanisms. Ageing Res Rev 2004;3:251263.

4 Papanikolaou G, Pantopoulos K: Iron metabolism and toxicity. Toxicol Appl Pharmacol 2005;202:199-211.

$\checkmark 5$ Zacharski LR, Chow BK, Howes PS, Shamayeva G, Baron JA, Dalman RL, Malenka DJ, Ozaki CK, Lavori PW: Decreased cancer risk after iron reduction in patients with peripheral arterial disease: results from a randomized trial. J Natl Cancer Inst 2008;100: 996-1002.

6 Nemeth E, Ganz T: The role of hepcidin in iron metabolism. Acta Haematol 2009;122: 78-86.

7 Shinzato T, Abe K, Furusu A, Harada T, Shinzato K, Miyazaki M, Kohno S: Serum pro-hepcidin level and iron homeostasis in Japanese dialysis patients with erythropoietin (EPO)-resistant anemia. Med Sci Monit 2008;14:CR431-CR437.

$\checkmark 8$ Hadley KB, Johnson LK, Hunt JR: Iron absorption by healthy women is not associated with either serum or urinary prohepcidin. Am J Clin Nutr 2006;84:150-155.
>9 Nagashima M, Kudo M, Chung H, Ishikawa E, Hagiwara S, Nakatani T, Dote K: Regulatory failure of serum prohepcidin levels in patients with hepatitis C. Hepatol Res 2006; 36:288-293.

10 Koca SS, Isik A, Ustundag B, Metin K, Aksoy $\mathrm{K}$ : Serum pro-hepcidin levels in rheumatoid arthritis and systemic lupus erythematosus. Inflammation 2008;31:146-153.

11 Tsuchihashi D, Abe T, Komaba H, Fujii H, Hamada Y, Nii-Kono T, Tanaka M, Fukagawa M: Serum pro-hepcidin as an indicator of iron status in dialysis patients. Ther Apher Dial 2008;12:226-231.

12 Ulukol B, Orhon FS, Hanoluk A, Akar N: Serum pro-hepcidin levels and relationship with ferritin in healthy non-anaemic infants. Acta Haematol 2007;118:70-72.

$>13$ Roe MA, Spinks C, Heath AL, Harvey LJ, Foxall R, Wimperis J, Wolf C, FairweatherTait SJ: Serum prohepcidin concentration: no association with iron absorption in healthy men and no relationship with iron status in men carrying HFE mutations, hereditary haemochromatosis patients undergoing phlebotomy treatment, or pregnant women. Br J Nutr 2007;97:544-549.

$\checkmark 14$ Hsu SP, Chiang CK, Chien CT, Hung KY: Plasma prohepcidin positively correlates with hematocrit in chronic hemodialysis patients. Blood Purif 2006;24:311-316.

15 Huang X, Fung ET, Yip C, Zeleniuch-Jacquotte A: Serum prohepcidin is associated with soluble transferrin receptor-1 but not ferritin in healthy post-menopausal women. Blood Cells Mol Dis 2008;41:265-269.
16 Kato A, Tsuji T, Luo J, Sakao Y, Yasuda H, Hishida A: Association of prohepcidin and hepcidin-25 with erythropoietin response and ferritin in hemodialysis patients. Am J Nephrol 2008;28:115-121.

17 Taes YE, Wuyts B, Boelaert JR, De Vriese AS, Delanghe JR: Prohepcidin accumulates in renal insufficiency. Clin Chem Lab Med 2004;42:387-389.

18 Lindenfeld J: Prevalence of anemia and effects on mortality in patients with heart failure. Am Heart J 2005;149:391-401.

19 Ezekowitz JA, McAlister FA, Armstrong PW: Anemia is common in heart failure and is associated with poor outcomes: insights from a cohort of 12,065 patients with new-onset heart failure. Circulation 2003;107:223-225.

-20 Groenveld HF, Januzzi JL, Damman K, van WJ, Hillege HL, van Veldhuisen DJ, van der MP: Anemia and mortality in heart failure patients: a systematic review and meta-analysis. J Am Coll Cardiol 2008;52:818-827.

21 Ueno H, Nakayama M, Kojima S, Kusuhara K, Nagayoshi Y, Yamamuro M, Nishijima T, Usuku H, Kaikita K, Sumida H, Yamabe H, Sugiyama S, Yoshimura M, Ogawa H: The synergistic combined effect of anemia with high plasma levels of B-type natriuretic peptide significantly predicts an enhanced risk for major adverse cardiac events. Heart Vessels 2008;23:243-248.

-22 Fukuta H, Ohte N, Mukai S, Saeki T, Kobayashi K, Kimura G: Anemia is an independent predictor for elevated plasma levels of natriuretic peptides in patients undergoing cardiac catheterization for coronary artery disease. Circ J 2008;72:212-217. 
-23 Tsuji H, Nishino N, Kimura Y, Yamada K, Nukui M, Yamamoto S, Iwasaka T, Takahashi H: Haemoglobin level influences plasma brain natriuretic peptide concentration. Acta Cardiol 2004;59:527-531.

-24 Kanda H, Kita Y, Okamura T, Kadowaki T, Yoshida Y, Nakamura Y, Ueshima H: What factors are associated with high plasma Btype natriuretic peptide levels in a general Japanese population? J Hum Hypertens 2005;19:165-172.

-25 Schikowski T, Sugiri D, Ranft U, Gehring U, Heinrich J, Wichmann HE, Kramer U: Does respiratory health contribute to the effects of long-term air pollution exposure on cardiovascular mortality? Respir Res 2007;8:20.

-26 Schikowski T, Sugiri D, Ranft U, Gehring U, Heinrich J, Wichmann HE, Kramer U: Longterm air pollution exposure and living close to busy roads are associated with COPD in women. Respir Res 2005;6:152.

27 Germing A, Gotzmann M, Rausse R, Brodherr T, Holt S, Lindstaedt M, Dietrich J, Ranft U, Kramer U, Mugge A: Normal values for longitudinal function of the right ventricle in healthy women $>70$ years of age. Eur J Echocardiogr 2010, E-pub ahead of print.

-28 Ranft U, Schikowski T, Sugiri D, Krutmann J, Kramer U: Long-term exposure to trafficrelated particulate matter impairs cognitive function in the elderly. Environ Res 2009; 109:1004-1011.

29 Kramer U, Herder C, Sugiri D, Strassburger K, Schikowski T, Ranft U, Rathmann W: Traffic-related air pollution and incident type 2 diabetes: results from the SALIA Cohort Study. Environ Health Perspect 2010, E-pub ahead of print.
30 Fleming DJ, Jacques PF, Tucker KL, Massaro JM, D’Agostino RB Sr, Wilson PW, Wood RJ Iron status of the free-living, elderly Framingham Heart Study cohort: an iron-replete population with a high prevalence of elevated iron stores. Am J Clin Nutr 2001;73:638646.

31 Wang JL, Shaw NS: Iron status of the Taiwanese elderly: the prevalence of iron deficiency and elevated iron stores. Asia Pac J Clin Nutr 2005;14:278-284.

32 Summary of a report on assessment of the iron nutritional status of the United States population: Expert Scientific Working Group. Am J Clin Nutr 1985;42:1318-1330.

33 Milman N, Byg KE, Ovesen L, Kirchhoff M, Jurgensen KS: Iron status in Danish women, 1984-1994: a cohort comparison of changes in iron stores and the prevalence of iron deficiency and iron overload. Eur J Haematol 2003;71:51-61.

34 Milman N, Pedersen AN, Ovesen L, Schroll M: Hemoglobin concentrations in 358 apparently healthy 80 -year-old Danish men and women: should the reference interval be adjusted for age? Aging Clin Exp Res 2008; 20:8-14.

35 Fernandez-Real JM, Equitani F, Moreno JM, Manco M, Ortega F, Ricart W: Study of circulating prohepcidin in association with in sulin sensitivity and changing iron stores. J Clin Endocrinol Metab 2009;94:982-988.

36 Kulaksiz H, Gehrke SG, Janetzko A, Rost D, Bruckner T, Kallinowski B, Stremmel W: Pro-hepcidin: expression and cell specific localisation in the liver and its regulation in hereditary haemochromatosis, chronic renal insufficiency, and renal anaemia. Gut 2004 53:735-743.
37 Ezeh C, Ugochukwu CC, Weinstein J, Okpala I: Hepcidin, haemoglobin and ferritin levels in sickle cell anaemia. Eur J Haematol 2005;74:86-88

38 Milman N, Schultz-Larsen K: Iron stores in 70-year-old Danish men and women: evaluation in 469 individuals by serum ferritin and hemoglobin. Aging (Milano) 1994;6:97103.

39 Cals MJ, Bories PN, Devanlay M, Desveaux N, Luciani L, Succari M, Duche JC, de Jaeger C, Blonde-Cynober F, Coudray-Lucas C: Extensive laboratory assessment of nutritional status in fit, health-conscious, elderly people living in the Paris area: Research Group on Aging. J Am Coll Nutr 1994;13:646-657.

40 Castagna A, Campostrini N, Zaninotto F, Girelli D: Hepcidin assay in serum by SELDITOF-MS and other approaches. J Proteomics 2010;73:527-536

41 Valenti L, Swinkels DW, Burdick L, Dongiovanni $\mathrm{P}$, Tjalsma $\mathrm{H}$, Motta $\mathrm{BM}$, Bertelli C, Fatta E, Bignamini D, Rametta R, Fargion S, Fracanzani AL: Serum ferritin levels are associated with vascular damage in patients with nonalcoholic fatty liver disease. Nutr Metab Cardiovasc Dis 2010, E-pub ahead of print.

42 Valore EV, Ganz T: Posttranslational processing of hepcidin in human hepatocytes is mediated by the prohormone convertase furin. Blood Cells Mol Dis 2008;40:132-138.

43 Ganz T, Olbina G, Girelli D, Nemeth E, Westerman M: Immunoassay for human serum hepcidin. Blood 2008;112:4292-4297. 